\title{
Le Cose dell'Antichità: Strada as a Student of Antiquity
}

\subsection{Profession: Antiquarius}

The foregoing chapters have attempted to provide an overview of what is known at present about the life and the career of Jacopo Strada. Some aspects which deserve more detailed consideration have only been touched upon in passing. For instance, an inventory and study of the libri di disegni on various subjects which Strada and his workshop provided to his patrons, a practice assiduously continued by his son Ottavio, would contribute to a better understanding of these interesting objects themselves, on the practice and functions of drawing, and on the intellectual aspects of encyclopaedic collecting in the later sixteenth century. An investigation of Strada's approach to numismatic method would throw light on the early history of classical scholarship and on the use of visual classical sources in the art of his period. ${ }^{1}$ A comparison of his career with that of similar personalities - in particular with other selfstyled 'antiquaries', but also with other agents, brokers, dealers and 'expert advisors' - would add to our knowledge of the dynamics of production, dissemination and reception of ideas, fashions and trends as well as of concrete cultural products. Such a comparison, however, can only be fruitful when the results of empirical research into the activities of a sufficient number of such professionals are available. The present study attempts to provide this for at least one such individual, Jacopo Strada.

The question remains whether at the time the varied group of professionals assuming or being indicated by the term 'antiquarius' was generally considered to belong to one single and established 'profession'. As a hypothesis this is doubtful, given that no commonly accepted, unequivocal term exists for representatives of such a profession. In his groundbreaking essay on the role of the antiquary in the study of ancient history, Arnaldo Momigliano complained:

1 This is the object of a research project at the Forschungszentrum Gotha, aimed at the digitization and the examination in context of Strada's numismatic corpus, the Magnum ac novum opus, preserved in the Forschungsbibliothek Gotha (cf. above, Ch. 3.3, and below, passim). The project is undertaken by Dr Volker Heenes and the author, with financial support of the Deutsche Forschungsgemeinschaft/DFG. 
'First of all we must ask ourselves who the antiquaries were. I wish I could simply refer to a History of Antiquarian Studies. But none exists'.2 In Momigliano's day the term antiquary referred to 'a student of the past who was not quite an historian'. The historian provided a chronological narrative interpreting the course of events - often to do with war and politics - and based his account on a selection of sources relevant to his argument. The antiquary collected and presented systematically and synchronically as many data relevant to a certain historical subject as he could find. His aim was erudition, not the writing of history. A second, related but distinct usage of the term contrasts historian and antiquary according to the type of source material they exploited. The historian tended to use mostly written and sometimes oral accounts of events, as well as archival materials; the antiquary concentrated on material remains of the past, such as inscriptions, coins, sculptures, paintings, buildings, arms, utensils and whatever other relics he dug up, sometimes literally, making him the precursor of the modern archaeologist; but he would occasionally also make use of archival material. The antiquary focused on the traditions of the distant past, studying religious and political institutions of earlier phases of a civilisation. He did this in part for their intrinsic interest, but also to stress their 'antique' dignity and value, and to serve as a moral example for posterity. The Renaissance rekindled the interest in such studies, which had never quite died out:

the notion of the "antiquarius" as a lover, collector and student of ancient traditions and remains - though not an historian - is one of the most typical concepts of fifteenth- and sixteenth-century humanism. ${ }^{3}$

Such passionate interest in remnants of the past could easily lead to severe criticism from sceptical spirits. An example is the lemma Robertus Stephanus' Thesaurus linguae Latinae of 1543 devoted to the term 'Antiquarius': here one meaning of the term is someone who is overly fond of ancient or old-fashioned formula's of speech, i.e. habitually uses pretentious, tasteless or obsolete phrases.

2 Momigliano 1950, p. 286. Since Momigliano antiquarianism has developed into a flourishing specialism within the humanities: aspects have been treated by Eric Cochrane's Historians and Historiography in the Italian Renaissance: (Cochrane 1981), in particular Ch. 15; Francis Haskell's History and its Images (Haskell 1993), Philip Jacks' The Antiquarian and the Myth of Antiquity: The Origins of Rome in Renaissance Thought (Jacks 1993), and in various collections of conference papers and collaborative studies, first of all many essays in the three volumes of Memoria dell'Antico nell'arte Italiano, edited by Salvatore Settis (Memoria Dell'Antico 19841986) and further Crawford/Ligota 1995; Miller 2007 and Miller/Louis 2012.

3 Momigliano 1950, p. 290. 
But this is a very specific use of the term. The very fact that several individuals such as Strada were proud to consider themselves 'antiquaries', show that such a negative connotation was in fact rare. ${ }^{4}$

The second significance given by Stephanus is much more general: 'Antiquaries are also called those who are assiduous students and experts of Antiquity'. So the word antiquarian, used both as a noun and as an adjective, could very generally indicate someone interested and, or knowledgeable in ancient things, including the writings of the past. In this sense the Renaissance humanists all were 'antiquarians': Stephanus did not distinguish between students of the texts and students of the material remains, and that distinction would have made no sense to a Renaissance antiquary. Though doubtless there were many scholars exclusively devoting themselves to literary testimonials of the past, there were no antiquaries exclusively studying its material remains. After all their interest in such objects was kindled by what they had read in the ancient historians; they needed the texts to identify and explain the objects, and used the objects to interpret or even correct the textual traditions. When Antonio Agustín speaks of Lazius as 'Volfango è molto antiquario, et buona persona et dotta', he used it in this general sense-perhaps even implying some of the positive moral qualities the term also could denote, as 'representing the simple virtues of the Ancients'. Yet we will see by the very example of Wolfgang Lazius and Jacopo Strada that in the sixteenth century the study of the material remains did develop into a specialized field of expertise.

In the Renaissance the term 'Antiquity' most often implied 'classical' Antiquity, the ancient civilizations of Greece and Rome; but that is not self-evident from Stephanus' lemma. In fact many antiquaries followed the precept of the classical study of 'antiquitates' in also devoting attention to other civilizations and epochs, in particular to the past of their own home towns, fatherlands or peoples. One example is the self-styled antiquarius John Leland, who laid the foundations of British historiography under the aegis of Henry viII. Certainly interest in the one did not exclude a lively interest in the other, witness the various references to Spanish history in Antonio Agustín's correspondence. ${ }^{5}$

That Leland styled himself 'antiquarius' implies that he must have had a clear concept of its meaning and that he expected others to share this-an

4 S.v. in: Robertus Stephanus, Dictionarium seu latinae linguae thesaurus non singulas modo dictiones continens sed integras quoque latine et loquendi et scribendi formulas (etc.), Editio secunda, Tomus 1, Parisiis (Robertus Stephanus), 1543. For other examples of the use of the word, see Momigliano 1950, p. 290, n. 1.

5 Cf. his discussion of the origin of the title of grandee of Spain in his letters to Onufrio Panvinio of 14 and 28 August 1557: Agustín 1980, nrs. 185-186. 
expectation warranted by the second clause of Stephanus' lemma. ${ }^{6}$ In the first half of the sixteenth century the term 'antiquarius' began to be used more often specifically for those who investigated, collected, documented and often published the material relics of the past, be it that of Ancient Rome or of their own local earlier civilization: ruins, tombstones, excavated sculptures, inscriptions, coins, gems, seals, as well as charters, diploma's and other archival documents. Like Leland and Strada, other students of the past, for instance Andrea Fulvio and Bernardo Gamuccio, expressly presented themselves as 'Antiquarius' on the title-pages of their books. Eric Cochrane's chapter 'Antiquities' gives a succinct survey of the many Italians of various background and education who exerted themselves in this field: lawyers, physicians, philologists, historians as well as architects and painters, such as Pirro Ligorio. Like most other disciplines of the period, such antiquaries based their studies always on the available classical sources: their interest in the material remains of Antiquity was partly based on their wish, as humanists, better to understand these written sources, whereas on the other hand these allowed the understanding or at least the interpretation of the material remains. ${ }^{7}$

It is unclear whether self-styled antiquaries such as Leland and Fulvio considered the study of antiquities as (a part of) their 'profession', but if they opted to identify themselves as such that seems not unlikely. If this was the case, they provide an earlier parallel to Strada, who did explicitly consider himself to exercise a 'profession' indicated by the term 'antiquarius. ${ }^{8}$ On the title page of Strada's earliest printed book, the Epitome thesauri antiquitatum of 1553, its provenance 'Ex Musaeo Iacobi de Strada Mantuani Antiquarij' is proudly indicated. ${ }^{9}$ When Strada was first employed by Ferdinand I in 1558 , he was appointed as a 'Baumeister', that is as an architect, and the second office he obtained after Maximilian II's accession is indicated in very general terms as 'Ein Diener von Haus aus'. Yet already in his own letter to the young King Maximilian of

6 Though Leland styled himself an antiquary in a pamphlet offered to Henry viII, there is no evidence that this title was attached to his function at court, cf. Momigliano 1950, pp. 313-314.

7 This point is made in Ingo Herklotz, 'Arnaldo Momigliano's "Ancient History and the Antiquarian": A Critical Review', in Miller 2007, pp. 127-153, in particular Section III: 'Literary and Non-Literary Sources'(pp. 136-141).

8 One might ask what Strada can have meant with he term 'profession', which itself has a range of connotations - from simple 'livelihood' or 'means of subsistence', via 'schooled craft or art' and 'vocation', to the explicit public presentation or 'profession' of a given science and/or conviction. All these connotations existed in the sixteenth century, and Strada's use of the term reflects at least some of them. Since he does not specify these, I have not attempted a further interpretation.

9 But Strada does not use the term on the earlier title pages of his albums of numismatic drawings in Gotha (1550, for Hans Jakob Fugger) and Paris (1554). 
June 1559, he states to be 'conossiuto per mondo provisionato da la Cesarea et [Vostra Maestà] per Jacomo Strada Antiquario'. Strada indignantly protested against Wolfgang Lazius having referred to him as a mere goldsmith, which Strada calls 'l'arte ch'io ho da putto imparato', and makes a clear distinction between this 'arte'-that is 'craft' or 'trade'-and his 'proffessione', which is devoted to 'le cose dell'antichità'. Strada claims that he could be outstanding in this, his chosen profession, just because he had mastered the trade of the goldsmith, so looked down upon by Lazius. Lazius' libel in fact had shown

... to Your Majesty and to the world how much I know and can do in my profession, in which I have not limited myself merely to know the names and to recognize the portraits of the ancient personalities [depicted on the coins], but have learnt by long and assiduous study not only to draw them on paper, but also to model them both in gold and other metals and in marble. ${ }^{10}$

Strada's understanding of the antiquary as a profession was not limited to numismatics, his own specialism and the subject of this letter. Besides documenting ancient coins, Strada himself also engaged in measuring Roman ruins and commissioned documentation of ancient sculpture and other figurative antiquities from other artists, implying that all such remains of ancient civilisations were worthy of careful study and were relevant to his 'profession' as an antiquary. Strada asserted that the knowledge of such material remains, and the art of correctly interpreting them, required both practical experience and specialized knowledge. These are professional qualifications: so,

...if Doctor Lazius, even though he is an erudite and learned historian, would remember that Greek proverb, he would not pretend to judge the profession of others, for it is not right that the cobbler should judge beyond his last."

This implies that Strada thought of the antiquary as someone contributing to the study of Antiquity in particular by a profound appreciation and knowledge of its material remains, which he collected, documented and studied in the

10 Doc. 1559-06-00; Jansen 1993(a), pp. 233-235; cf. above, Ch. 4.2. In an earlier letter to King Ferdinand I [Doc 1558-02-21b] Strada had explained the insufficient result of the coincatalogue planned by Lazius and the local engraver Hans Sebald Lautensack by their lack of 'professional' experience.

Doc. 1559-06-oo, Strada to Maximilian II; Jansen 1993(a), pp. 233-235; cf. above, Ch. 4.2. 
light of the written sources available. He shared the results of his study with other scholars, but also made it available to a more general public, including artists and their patrons. Both the sharp and critical eye and the ready hand he owed to his artistic training were necessary qualifications for the successful exercise of this specialization. Strada shared these qualifications with the three other artist-antiquaries, his near contemporaries, with whom he was associated in an often-quoted passage from Antonio Agustín's Dialogo delle Medaglie:

A[gustín]: Of the Circus Maximus, and other [circuses] that were in Rome I have seen no medals, but only certain drawings of my friend Pirro Ligorio from Naples, a great antiquarian and painter, who without knowing Latin has written more than forty books of [ancient] medals, and of buildings and of other things.

B.: How can that be, that without understanding Latin he could have written well about such things?

A.: In the same way as do Humberto Golzio, Enea Vico, Iacopo Strada, and others, so that who reads their books would believe that they have seen and read all the Latin and Greek books that ever were written. They make use of the labour of others and being able to draw well with a brush, they wield a pen equally well. ${ }^{12}$

It is actually not easy to understand what Agustín exactly meant with this remark. Considering that elsewhere he had spoken with appreciation of Ligorio's and Vico's efforts, had supported Strada against Lazius, and included all

12 Agustín 1587, pp. 131-132: 'Del circo Maximo, y de otros que hauia en Roma no he visto medallas, solamente he visto ciertos debuxos de Pyrrho Ligori Napolitano, conocido myo gran antiquario, y pintor, el qual sin saber Latin ha escrito mas de quarenta libros de medallas y edificios, y de otras cosas. B. Como puede ser, que sin saber Latin sepa escriuir bien destas cosas? A. Como escriuen Humberto Volcio [sic] y Enea Vico y Iacomo Estrada, y otros que quien lee sus libros pensara que han visto, y leido todos los libros Latinos, y Griegos que hai escritos. Ayudanse del trabajo de otros, y con debuxar bien con el pinzel, hazen otro tanto con la pluma. Pero boluamos à las medallas.'; in the Italian translation by Dionisio Ottaviano Sada, Agustín 1592 (a), pp. 117: 'Del Circo Massimo, e d'altri che erano in Roma non n'ho vedute medaglie, ma solamente n'ho veduti certi disegni di Pirro Ligori Napoletano mio conoscente grande antiquario, e pittore, il quale senza saper latino ha scritto più di quaranta libri di medaglie, d'edifitij, e d'altre cose. B. Come può essere che senza sapere latino possi scrivere bene di queste cose? A. Come scriue Humberto Goltzio, et Enea Vico, et Iacomo Strada, et altri che chi legge i loro libri penserà che habbino veduto, e letto tutti i libri Latini, e Greci che sono scritti, aiutonsi delle fatiche d'altri, e con disegnar bene col pennello fanno altro tanto con la penna. Ma torniamo alle medaglie<...>'; another translation published in the same year by Ascanio Donangeli (Agustín $1592(b)$. 
four in the bibliography of his treatise, it cannot have been intended in a derogatory sense. ${ }^{13}$ Though Ligorio may have had little Latin and less Greek, the other three easily read and adequately wrote in Latin. Strada's lexicographical enterprise and the description of Greek coins in his manuscript A.A.A. Numismat $\Omega n$

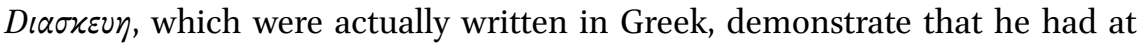
least a basic command of that language. Agustín merely implied that these erudite artist-antiquaries drew primarily on modern editions and-in Ligorio's case - translations of ancient texts, and on modern commentaries and secondary literature for the facts and interpretations included in their voluminous compilations. If such was his intention, Strada may well have agreed with him: while attacking Lazius in his letter to Maximilian II, he does give him his due as an 'erudite and learned historian', a 'profession' to which he himself did not pretend, though he respected it just as he expected Lazius to respect his.

It seems no coincidence that Agustín coupled the names of Ligorio, Vico, Goltzius and Strada: though the emphasis differs in each case, their activities largely overlap, and their approach seems very similar [Figs. 15.1-15.4]. Certainly Strada was aware of their existence and their work, and it is very likely that he personally knew them, perhaps already from his stay in Rome in the 1530 s and 1540 s, if not from his stay in Rome in $1553-1555$. In his letter to Maximilian II he cites an opinion of Pirro Ligorio as an authority, and he certainly frequented Enea Vico in Venice in the mid-155os: Vico cited coins from Strada's collection, just as Strada cited coins from Vico's, and they also copied or exchanged each other's drawings of ancient sculpture. Moreover, at some time Vico was presented with a coin from Fugger's collection through Strada's mediation. But Strada knew Vico by reputation even before that, and seems to have been influenced by Vico's earlier numismatic works. ${ }^{14}$ In his exhaustive

13 The English translation as given in Stenhouse 2005, p. 8o, is mistaken: Spanish 'otro tanto', in the Italian translation 'altro tanto' (modern: 'altrettanto') means 'just as much', 'equally', not 'otherwise'. The free translation given in Mandowsky/Mitchell 1963, pp. 30-31 implies the same mistaken interpretation. Agustín's esteem of his antiquarian friends was definitely more positive that these translations suggest: 'though they made use of the research done by others, they wrote as well as they drew'.

14 Bodon 1997, pp. 61-67, 172, 176; Jansen 1993(a), pp. 232. Vico's Le Imagini con tutti i riversi trovati et le vite degli $[X I I]$ imperatori tratte dalle medaglie et dalle historie degli antichi<...>, published by Zantani in 1548 (Vico 1548) must have impressed Strada for its elegance and the precison of its images. The idea to include empty circles illustrating emperors of which no authentic coin had (yet) been found, and the addition of elegant frontispieces with an 'elogio' for each emperor are among the aspects Strada practises in his own Epitome and/or his manuscript numismatic albums. Vico moved to Ferrara before Strada's visits to Venice in 1566-1569, so he was not among the 'orefici o disegnatori di stampe in rame, o miniatori' with whom Strada associated according to Nicolò Stopio's letter of 

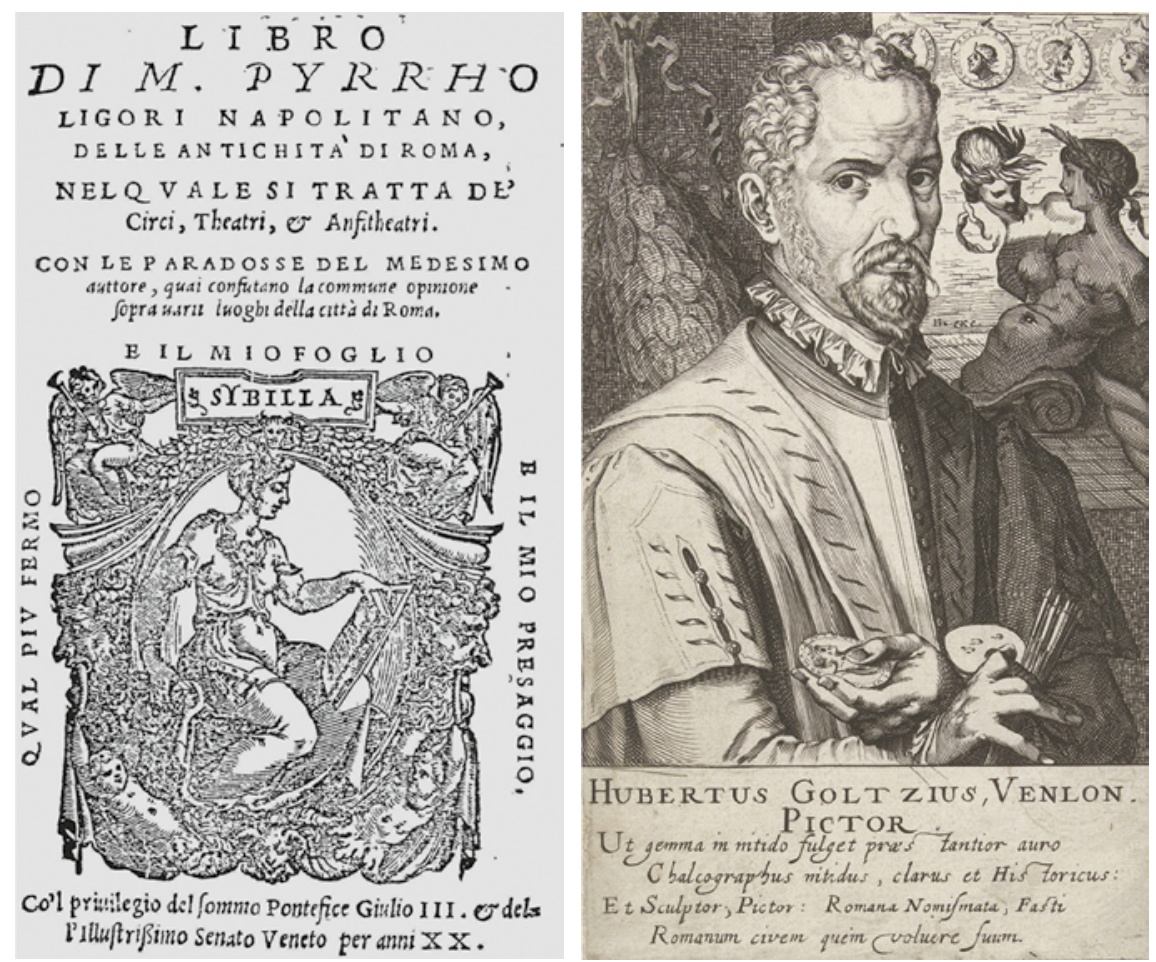

FIGURE 15.1 Pirro Ligorio, the title page of his Libro delle antichità di Roma, nel quale si tratta de' circi, theatri et Anfitheatri, Venice 1553 .

FIGURE 15.2 Simon Frisius, after Antonio Moro, portrait of Hubertus Goltzius; engraving from Effigies pictorum aliquot celebrium praecipué Germaniae inferioris, The Hague, 1610.

study on Vico, Giulio Bodon moreover suggests a hypothetical project of collaboration between Strada and Vico, on the basis of their shared interest in the designs of the friezes of the Columns of Trajan. ${ }^{15}$ Strada's letter to Maximilian II suggests that, as an antiquary, he would have felt most akin to these three artist-antiquaries, and the passage from Agustín's treatise implies that such a conception of the antiquary as a professional combining erudition and artistic prowess was not unusual.

15 June 1567 [BHStA-LA $485^{2}$, fol. $35^{-36 / 29-30 ; ~ c f . ~ a b o v e, ~ C h . ~ 2.5 .2] . ~ B u t ~ t h e y ~ a p p e a r ~ t o ~}$ have corresponded, and Strada remained in contact with the Ferrara court also through Giovan Battista Pigna, Alfonso II's secretary and historiographer.

15 Bodon 1997, p. 82. 

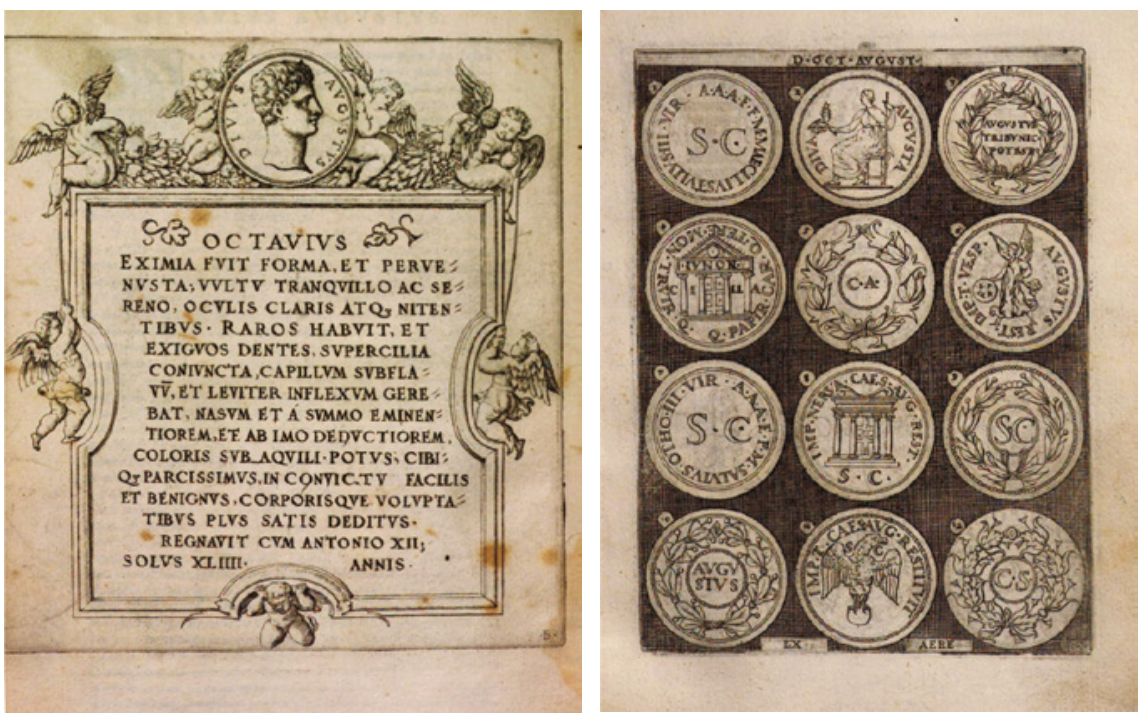

FIGURES 15.3-15.4

Enea Vico, the pages showing the obverse and the reverses of the coins of Augustus, in his Omnium Caesarum verissimae imagines ex antiquis numismatis desumptae, s.l. 1554 .

\subsection{Strada's Qualities as an Antiquary}

The passage in Agustín's Dialogo delle medaglie quoted above shows that in his own time Strada enjoyed a wide reputation as a learned antiquary, at least among the general public. As already indicated in the first chapter, this reputation did not survive the seventeenth century, if so long. His publications were not sufficiently reliable and precise to be of any use to later archaeologists. Moreover, it is clear that, though he recognized and emphasized the value of the artefacts he studied for the history of Antiquity, his use of them was rather limited. In the first place he was only really expert in ancient numismatics, and even then considered the ancient coins primarily for the iconographic information they provided, that is, the features of the historical personalities depicted in their obverses, and the symbolic, emblematic images adorning their reverses. He obviously was aware of the value of such visual material to aid the historical imagination, stressing in a letter to Jacopo Dani that for his Series he had selected the most beautiful and rare large medals, and 'quelli che portano la historia con essi'. ${ }^{16}$

16 Strada to Jacopo Dani, 17 June 1573 (Doc. 1573-06-17): 'Ora Vostra Signoria sappia che doppo ch'io son vivo, non ò mai fatto altro che accumular medaglie e coppie di esse, et la mia 

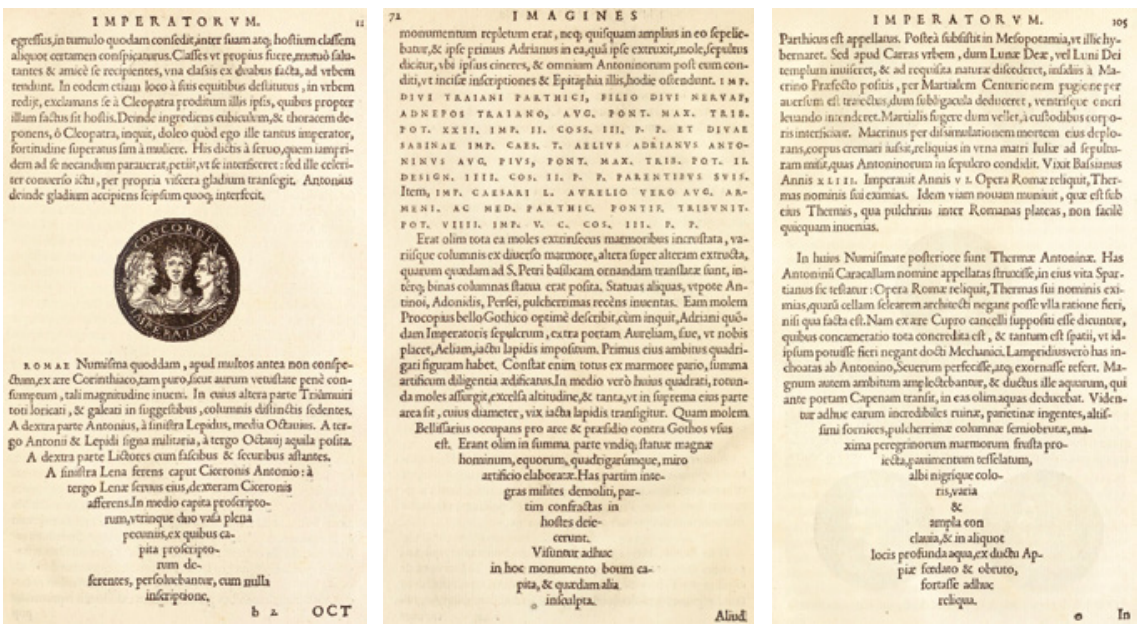

FIGURES 15.5-15.7 Pages from Strada's Epitome thesauri antiquitatum, Lyon 1553: image of a coin of the Triumvirs and the description of its reverse (p. 11), and descriptions of the Mausoleum of Hadrian (p. 72) and the Baths of Caracalla (p. 105).

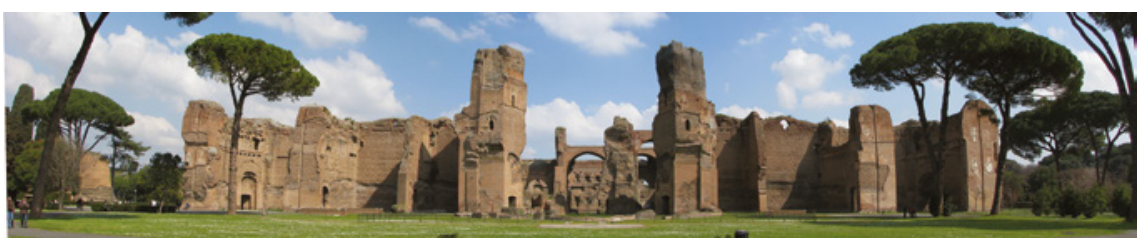

FIGURE 15.8 The Baths of Caracalla in their present state of ruined grandeur.

This suggests that Strada saw his 'medaglioni' primarily as illustrations of ancient history as known from literary sources. Though he probably grasped the significance of the more adventurous investigations of contemporaries such as Pirro Ligorio, which he probably knew about, and Guillaume du Choul, with whom he was intimate and whose research he supported, he hardly used the material he had collected to draw new conclusions on specific aspects of classical civilization himself.

The only exceptions to this were the fields of architecture, warfare and public festivities. Strada's interest in the military strategy and the engineering feats of the Romans is evident in the surveys he collected or commissioned of the friezes of the Columns of Trajan and Marcus Aurelius in Rome and that of Arcadius in Constantinople, of Serlio's illustrations of Polybius, and of the reconstructions of Caesar's battles he published in his 1575 edition of the

Series è tanto coppiosa quanto imaginar si possa; et sempre ò pigliato medaglioni, li più belli e li più rari, et quelli che portano la historia con essi, che io habbia fra di essa.' 

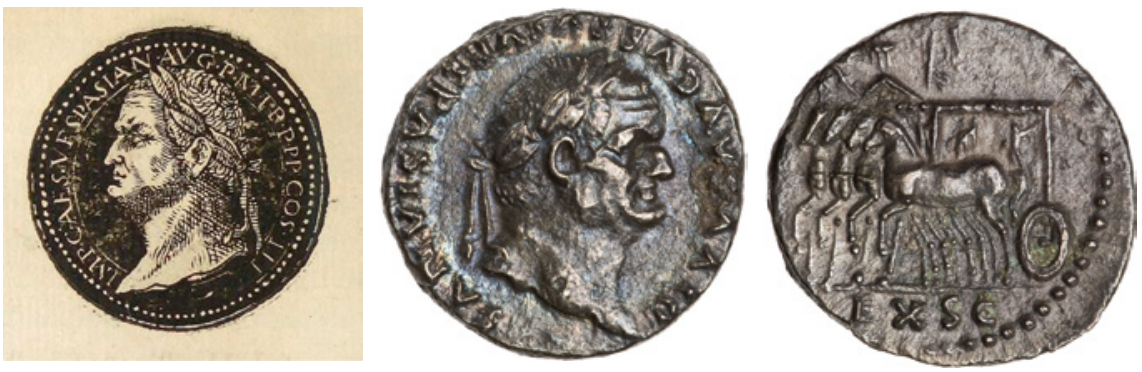

FIGURES 15.9-15.11 The image of Vespasian from Strada's Epitome, and an exemplar of the coin type on which he may have based his description of a reverse.

Commentaries. His interest in the architecture of the ancients is evident not only in his measurements of Roman ruins, but also in his descriptions and reconstructions of the buildings depicted on the architectural reverses of the coins he documented. Surely it is no coincidence that of the reverses Strada selected to describe in his Epitome thesauri antiquitatum - one, occasionally two for each Emperor - a very large number depicted a monument dating to the reign of that ruler.

In several instances Strada complemented his description of the reverse with a succinct description of the monument itself, based on the available literary sources, but often also including references to relevant inscriptions. Examples are the Mausoleum of Augustus, the aqueduct of the Aqua Claudia, the Colosseum; his description of the 'Palatium Nervae' is so detailed, and includes an inscription of such a length, that it is evident that he cannot have used an authentic medal or a coin as his (only) source. Other examples are the Circus Maximus and the Pons Aelius, followed by a description of both the bridge and the adjoining mausoleum of Hadrian, now the Castel Sant'Angelo [Fig. 15.6]. ${ }^{17}$ Occasionally Strada's phrasing suggests his first-hand observation — or rather admiration — of the relics of such monuments, for instance when he comments on the 'Thermae Antoninae', the Baths of Caracalla [Fig. 15.7 and 15.8]:

... in fact one still sees their incredible ruins, huge walls, most high vaults, most beautiful columns half-standing, large marbles broken and

17 Strada 1553(a), pp. 18-19 (Tiberius); 27-28 (Claudius); 56 (Titus); $62-63$ (Nerva); 65-68 (Trajan) and 71-72 (Hadrian). Other coin reverses described as showing public and religious buildings are those of Augustus (Temple of Peace), Didius Julianus (Temple with Ionic columns), Septimius Severus (Septizonium), Heliogabalus (Temple), Alexander Severus (Colosseum and Triumphal Arch of Titus). For a more detailed listing, see Heenes 2003, pp. 18-20. 

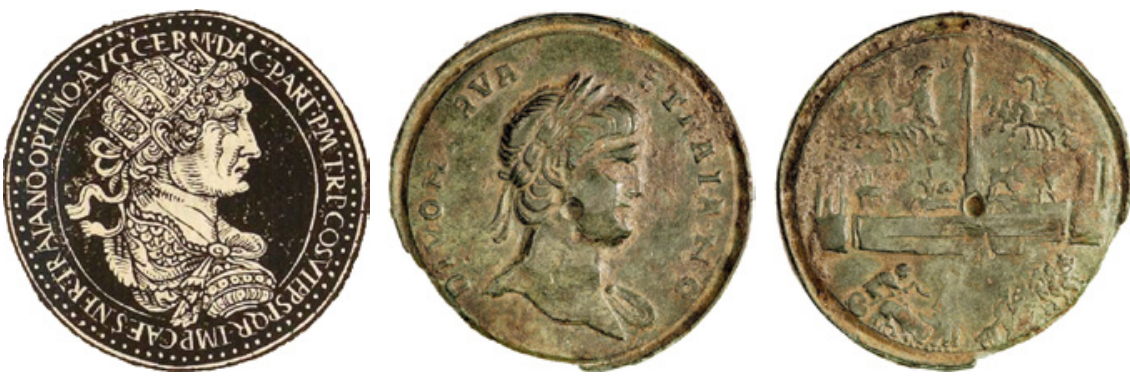

FIGURES 15.12-15.14 The image of Trajan from Strada's Epitome, and an exemplar of the coin type on which he based his description of a reverse.

dispersed, floors in mosaic in black and white, various and spacious rooms, and in some spots deep basins full of water conducted by the Appian aqueduct now mostly damaged or ruined. ${ }^{18}$

In view of Strada's later involvement in festivals organised at the Imperial court, it is of some significance that he also paid detailed attention to public festivities in classical Rome. Thus for Vespasian [Fig. 15.9] he selected a reverse illustrating the Emperor's triumph after having subdued the Jewish revolt, using an example close to a type actually struck under Titus, interpreting it as the triumphal curricle carrying the Emperor and his son Titus preceding a procession of the spoils of war [Figs. 15.10-15.11]. ${ }^{19}$ Strada then added two and a half pages describing the triumph, a passage taken straight from Book VII of Flavius Josephus' Judean War. ${ }^{20}$ Though he did not mention it, he may well have selected this event because it is so well documented in the beautiful reliefs of the Arch of Titus in the Forum Romanum.

For Trajan [Fig. 15.12] he selected not one of the coins illustrating the famous Column, still standing in the centre of the remains of that Emperor's forum, as might have been expected in view of his later interest in that monument,

18 Strada $1553(\mathrm{a}), \mathrm{p} .105$.

19 Here, as elsewhere in this chapter, I have presented coin images of which the visual qualities are such that they may have served as Strada's sources; I have not attempted a definitive identifcation of the particular coin types Strada used. Such an identifcation has been undertaken by Volker Heenes, whose findings and critical analysis of Strada's numismatic practice will become available with the results of our collective research project, Jacopo Strada's Magnum ac Novum Opus: A Sixteenth-Century Numismatic Corpus, which is financed by the Deutsche Forschungsgemeinschaft and based at the Gotha Research Centre of the University of Erfurt (FZG). Not wishing to anticipate his findings, I have not revised this section of my thesis, except as to find better exemplars of the coin-types I discuss.

20 Strada 1553(a), pp. 50-52; the text corresponds to Flavius Josephus's Jewish War, Book viII, 116-155, cf. Josephus/ Thackeray 1961, pp. 538-551. 
but a coin showing the Circus Maximus, pretext for a similar disquisition on the Circus itself, and in particular of the games and chariots races for which it was used, including a description of the pompa circensis, the richly apparelled entry procession [Fig. 15.13-15.14]. ${ }^{21}$

Finally Strada used a coin-type of Domitian for a short explanation of the Secular Games or Ludi Saeculares. He described not so much these games themselves as the three days of religious sacrifices and ceremonies that preceded them, doubtless again basing himself on classical texts. It is such dependence on literary sources that Agustín meant when he contended that Strada and his fellow antiquaries 'made use of the labour of others'. Indeed, in his text Strada repeatedly refers to the literary sources he had used for individual passages, and he pays ample tribute to the many friends and colleagues who had contributed to the material he collected and with whom he had critically discussed his finds and their interpretation.

In his preface Strada compares his effort favourably with those of existing and prospective rivals, thinking that none of them could beat him as to the quantity of images included, or the diligence in which he had searched for them. He stresses the importance of critically examining each item in order to select true, ancient exemplars and to avoid modern counterfeits, being perfectly aware that 'nowadays one finds so many excellent and subtle sculptors, that truly they merit to be prized no less than the ancients [themselves]'. For the same reason one should carefully consider the workmanship of each object: Strada claims to have done his utmost to select images of outstanding beauty and elegance.

His selection of the reverses described doubtless reflected Strada's own interests. His preface was probably a sincere statement of his intentions; and his Epitome thesauri antiquitatum did satisfy the very many contemporaries who wished to own a copy. Yet it is not surprising that it did not satisfy later serious numismatists, for the book was in fact not very numismatic in character. Though the ancient coins at first sight appear to be its raison d'être, and in its preface Strada did talk about the ample quantity of coins he had documented, the coins of which he illustrated the obverses are never described as objectsnot even the metal is given - and it seems that the reverses described are rarely related to the obverses illustrated [cf. Figs. 15.9-15.14]. The clue to this enigma can be found in the subtitle of the Latin version:

21 Strada 1553(a), pp. 65-68, again based on sources ('ex variae autoribus desumptam'). Strada refers to Dio Cassius and 'Sextus Ruffus', the mysterious author of the treatise De regionibus Urbis Romae first published by Onofrio Panvinio (Frankfurt 1558), which Strada quoted either from the manuscript in the library of Monte Cassino or, more likely, from extracts inserted in Flavio Biondo's Roma instaurata (Verona 1482); cf. Jacks 1993, pp. 116, 311. 

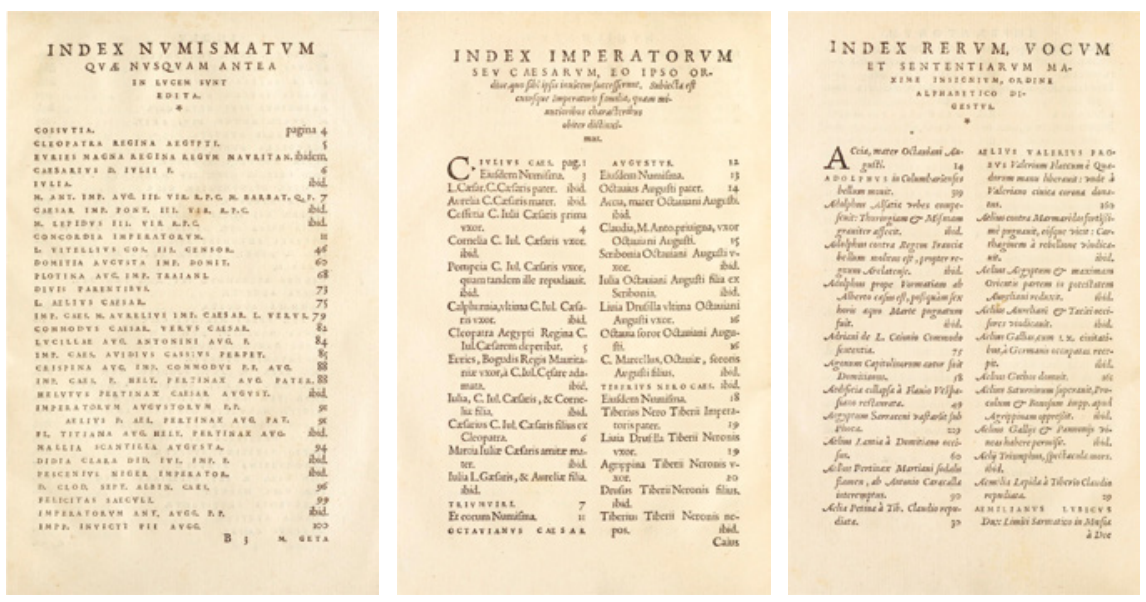

FIGURES 15.15-15.17 The three indices appended to Strada's Epitome thesauri antiquitatum: a list of coin-inscriptions not published earlier, a chronological register of the individuals included, and an alphabetical index.

\author{
Epitome Thesauri Antiquitatum, \\ hoc est, IMPP. Rom. Orientalium et Occidentalium Iconum, \\ ex antiquis Numismatibus quam fidelissimè \\ deliniatarum
}

\begin{abstract}
Abridgment of the Treasure house of Antiquities, That is, Images of the Roman Emperors of the East and the West most faithfully drawn after [their] ancient coins
\end{abstract}

This makes clear that the book was not intended primarily as a manual for collectors of ancient coins. The medals merely served as the source for the images, the portraits or effigies of the Emperors, the lives and connections of whom are the true object of the book and of its intended readership. From that point of view the book makes sense: basically it is a relatively careful and precise compilation of historical facts taken from literary sources, aiming to make the history of the Roman Empire, including its Byzantine and German successors up to the present day, easily accessible to a well-educated, but not necessarily scholarly audience. The French edition Strada published simultaneously shows that he aimed at a wide-ranging readership. Thus, the Epitome fits squarely into the tradition of Bildnisvitenbücher first investigated by Paul Ortwin Rave. ${ }^{22}$

22 Rave 1959; see also Haskell 1993, Chs. A and 2; Cunnally 1999, passim.; Heenes 2003, pp. 18-20; Heenes 2010. 
Strada did try-or at least pretended — to present historically valid images, based on existing coins or-when these were lacking - on seals or other material sources. This distinguishes both the contents and the readership of his book from those of more fanciful bestsellers such as Guillaume Rouillés Promptuarium. It is useful to compare Strada's Epitome also with a more serious competitor such as Enea Vico's Le immagini con tutti i riversi trovati et le vite de gli imperatori, printed in Venice in 1558 . The latter is more elegant and shows the images of many reverses, but it is limited to the first twelve Emperors. Strada's treatise is far more comprehensive: it provides a repertory of all those individuals who had attained or pretended to the purple and their dependents. Moreover, Strada's compilations of their biographies, though eminently readable, are more serious and far more detailed.

The apparatus which Strada's adds to his volume corroborates its intended function as a work of reference. Only the first of the three indices has a truly numismatic function: this is a list of the inscriptions of all those coins he included which had not been published earlier [Fig. 15.15]. The other two are a chronological index of all personages included and a very comprehensive alphabetical index, including references both to these personages again (printed in capitals) and to events and objects discussed (printed in italics) [Fig. 15.1615.17]. This section closes with a page listing 'Errata sic corrigito.'23

\subsection{Strada's Method}

In addition to these indices, Strada also included a family tree clarifying the genealogy of the Julio-Claudian dynasty into the Epitome. Though it cannot compare in splendour and detail with Enea Vico's huge print of 1555 showing the genealogical ramifications of the first twelve Emperors with surprising precision, Strada's scheme shows that he was well aware of the use of such up-to-date graphical aids to quick comprehension [Fig. 15.18]. ${ }^{24}$

Strada owed such systematic rigour to his close connections with Hans Jakob Fugger and the very learned men of his circle, such as the zoologist and bibliographer Conrad Gesner and the Greek scholar Hieronymus Wolf, who served as Fugger's librarian and who developed the intricate and efficient shelving system which was later adapted for use in the library of Duke Albrecht

23 Strada 1553(a), fol. B3r-C3r.: 'Index numismatum quae nusquam antea in lucem sunt edita'; fol. Cv.-E3r.: 'Index imperatorum seu caesarum, eo ipso ordine, quo sibi ipsis invicem successerunt'; fol. E3v.-L3r.: 'Index rerum, vocum et sententiarum maxime insignium, ordine alphabetico digestus'.

24 I am grateful to Dr Ulrike Peter to have drawn my attention to the Vico print, on which see Peter/Rubach 2011; Strada's genealogy mentioned and illustrated on pp. 90-91. 


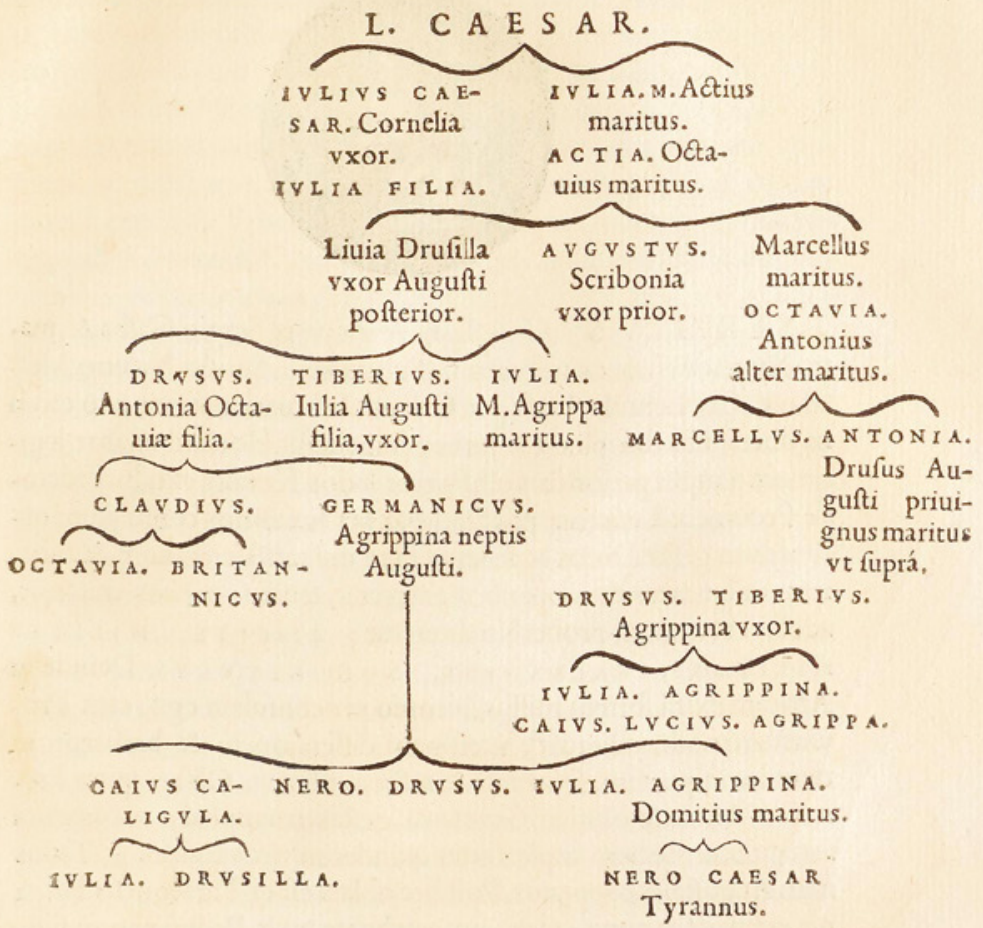

A G R I P P I A Germanici filia,oppido Vbiorum fuit nata, à qua \& deinde Agrippina colonia denominationem accepit.

FIGURE 15.18 Family tree of the Julio-Claudian dynasty, inserted into Strada's Epitome thesauri antiquitatum after the chapter of its last Emperor, Nero. 
V of Bavaria. This was done by Samuel Quiccheberg, who in his turn used his experience to develop his own treatise on the setting up and ordering of a universal collection, the Inscriptiones vel tituli theatri amplissimi of 1565 . Being so much at home in Fugger's circle, Strada could fall back on such examples to develop some sort of 'content-management' system of his own to classify the vast quantity of documentary images he collected and exploited, in order quickly to find a particular text or image needed. A project such as the lost polyglot dictionary is inconceivable without some such filing system. To organise the more than nine thousand drawings of coins included in Strada's Magnum ac Novum Opus preserved in Gotha, he must have kept quite precise records, especially considering that he employed several draughtsmen in the manufacture of this and the various other numismatic manuscripts he offered to his patrons. The originals of the careful, rigorously uniform descriptions of obverse and reverse of each coin that his scribes copied into the versions of

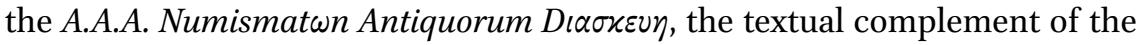
Magnum ac Novum Opus, must have been kept with the original drawings, or in a parallel, corresponding set of files or card index.

The uniform formula Strada developed for these descriptions likewise probably reflects methodical practice current in Fugger's circle, in particular the uniform entries on individual authors in Conrad Gesner's Bibliotheca Universalis. ${ }^{25}$ Each entry gives a standardised methodical description first of the obverse, than of the reverse of the coin, always concluding with its inscription; the entry always closes with a mention of the specimen on which the description is based, naming the metal, providing an indication of its size and sometimes its quality, and the collection in which Strada had seen it, for instance: 'This most elegant and large coin was shown to us by Julius Romanus in Mantua: ${ }^{26}$

The contents of these descriptions are as interesting for what they omit as for what they include. Strada must have been aware of the usage as currency of the coins he described, and he did at least distinguish the material of his exemplars. But he did not specify their exact size and weight; consequently the currency value of the coins are not noted. This suggests that his interest in them was primarily iconographical: his aim was to reproduce the images, to identify the portraits on the obverses and the objects on the reverses, and then to interpret their symbolism and to explain their historical significance.

25 On Fugger's circle, see above, Chs. 3.1 and 3.2. Strada's numismatic practice merits a more detailed investigation than is possible here; in addition the empirical, methodological aspects, it might be worthwhile to define the role played by the ekphrasis, the verbal description of a work of art (e.g. the shield of Achilles in the Iliad) that was an element in classical rhetoric, and of which Strada must have been very much aware.

26 A discussion of these descriptions and the drawings to which they relate in Jansen 1993(a), pp. 216-220; some examples are given in its annex 1 (pp. 227-230). 
Beginning with the obverse of the coins, he succinctly described the Emperor's profiles, indicating the direction of the face, the dress and (laurel) crown and other attributes, if any, and he transcribed the inscription. But he did not refer to written sources describing the appearance of the emperors, though in many cases these were available, and neither did he comment on the expression of their faces. Both as an artist and as a courtier Strada realized that these images were official representations, designed to project a positive, but not necessarily truthful image of the ruler.

When he turned to the reverses, however, Strada's approach was much less discrete, and he was much quicker prepared to interpret what he saw in the light of his historical knowledge. Though the descriptions have a similar structure as those of the obverses, the objects depicted are often not merely described, but also identified-especially when they represent triumphs or games organized, and public works or monuments realized during the reign of the Emperor

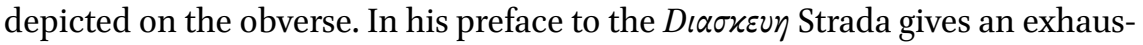
tive list of the types of military and civil institutions and of the monuments documented in such coins. He moreover claims that he conferred these images with the remains of the original constructions, if still extant. Though he does not cite the relevant sources, it is obvious that his identifications were based both on ancient texts and on the authors of the later antiquarian tradition, such as Flavio Biondo's Roma Instaurata. As in the Epitome, the images documenting monumental buildings are exhaustively described, in far greater detail than was warranted by the image on the actual coin.

That in these descriptions Strada, instead of documenting an individual coin type, reconstructs the monument depicted on it, is corroborated by the related drawings in his numismatic albums. Thus Strada's drawing of a coin type of Trajan showing the Circus Maximus, roughly five times the size of the actual object, shows many worked-out details which are not found, and could not have been shown in the coin [Figs. 15.19-15.20].

The same holds for Strada's drawing of a reverse of a coin of Trajan which is traditionally interpreted as (a section of) the famous bridge across the Danube

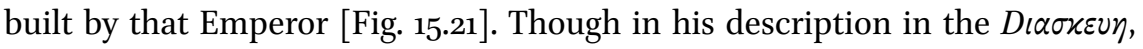
Strada mentions that possibility, he himself interprets it as a 'portus', a harbour, naval arsenal or boathouse. His corresponding drawing [Fig. 15.22] owes much to contemporary representations of the principal element of a theatre for a Naumachia or mock sea-battle, such as those included in Pirro Ligorio's Anteiquae Urbis Imago [Fig. 15.23]. Strada's suggestion that the object represented on the coin is not a bridge at all is not implausible and in any case demonstrates the ingenuity and creativity of his approach. ${ }^{27}$ 

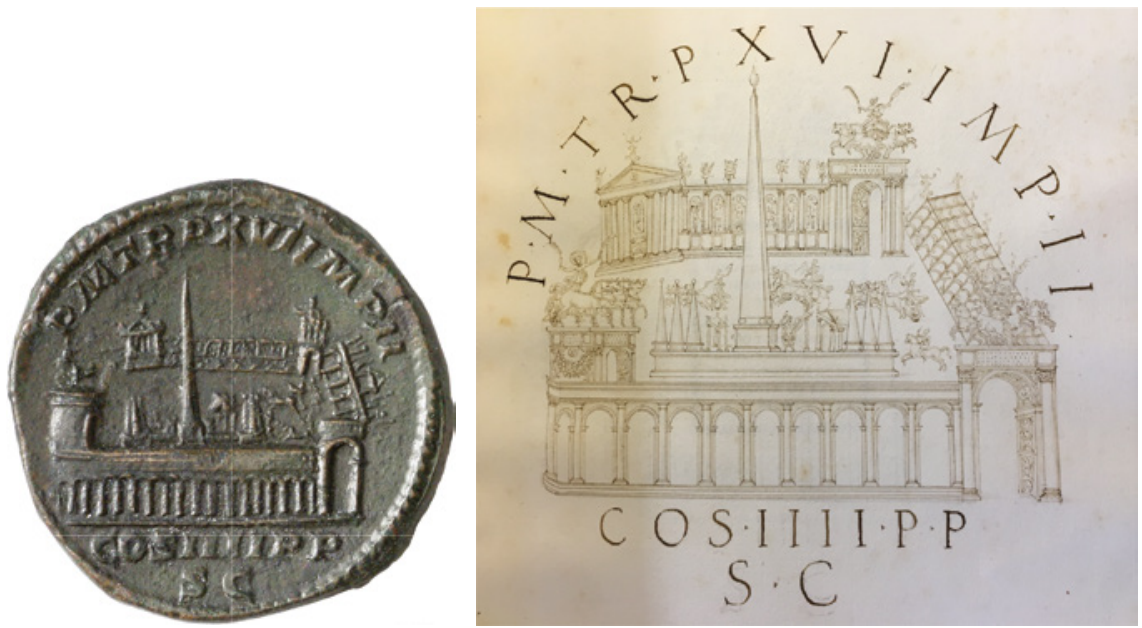

FIGURES 15.19-15.20 Reverse of a coin of Trajan, showing the Circus Maximus, compared to Strada's design of a similar type, in his Vienna Series, ÖNB-HS, ms. 9414, fol. 96 .
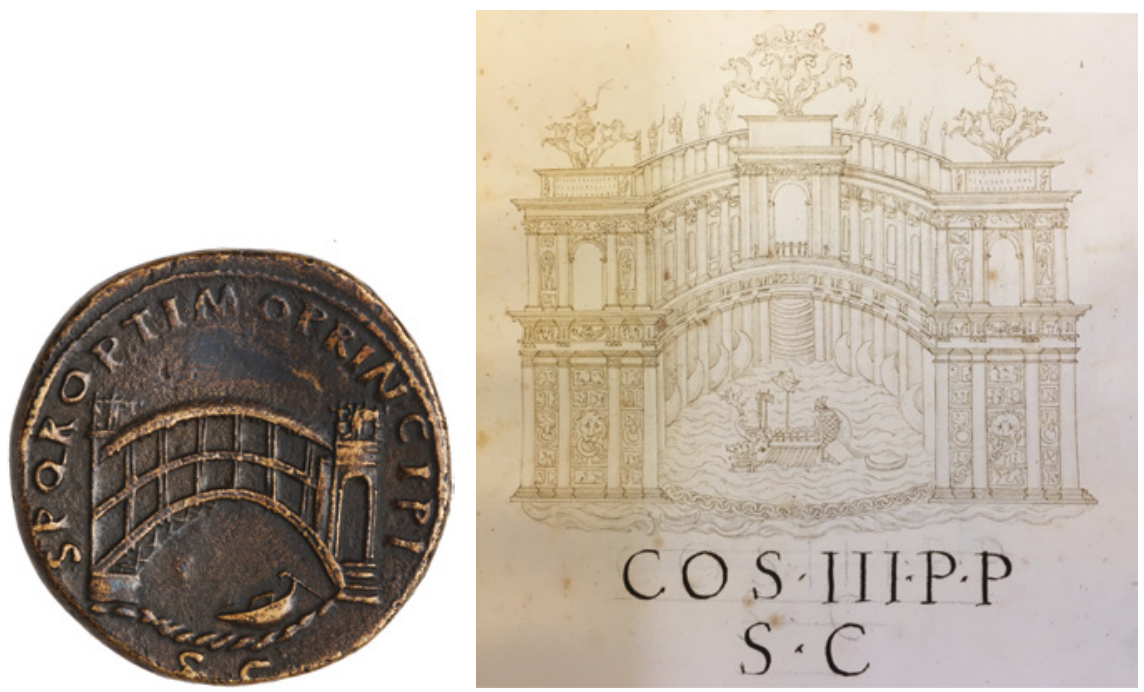

FIGURES 15.21-15.22 Reverse of coin of Trajan, showing a bridge (?) and Strada's drawing of a similar type, in his Vienna Series, önb-hs, ms. 9414, fol. 88, interpreting it as a boathouse or a theatre for staging naval battles or Naumachia.

Strada appears to have derived some elements from a coin type of Nero, depicting a triumphal arch [Fig. 15.24], for his drawing of the reverse of an unidentifed, probably spurious coin he assigned to Vespasian [Fig. 15.25]. But his drawing again shows a wealth of detail which could never have been readable in his model. In fact, such Mannerist detail looks suspiciously similar to that of ephemeral arches designed for festive entries of Strada's own time, to which he occasionaly contributed designs, rather than to the still existing antique 


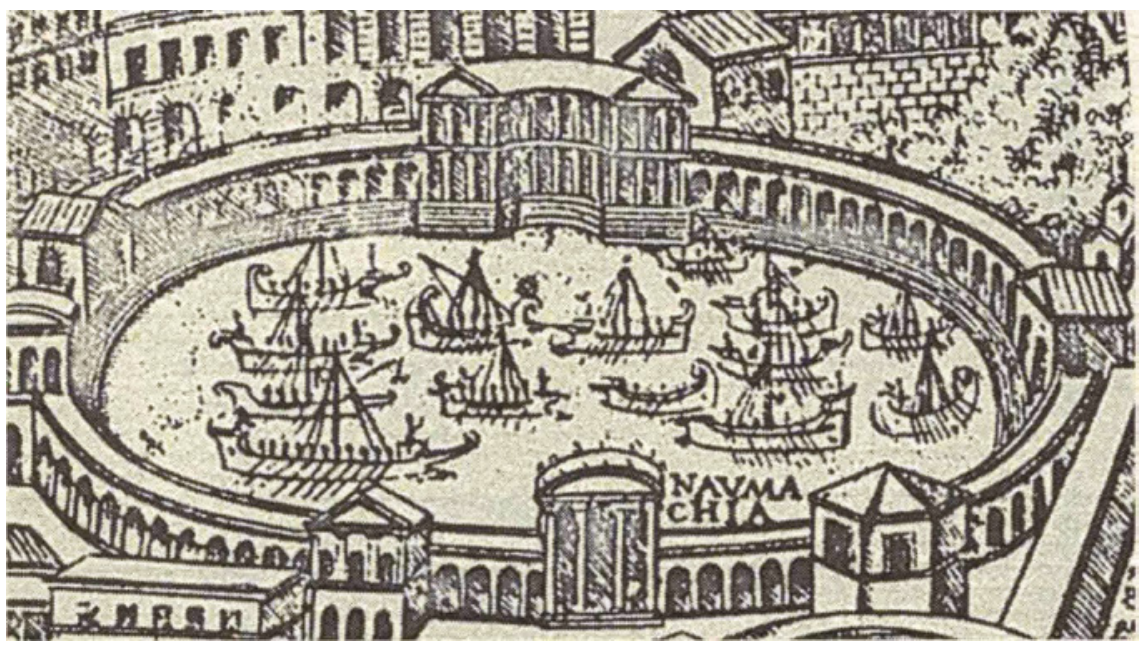

FIGURE 15.23

Pirro Ligorio: reconstruction of a Roman Naumachia, detail of his Anteiquae Urbis Imago (1561).
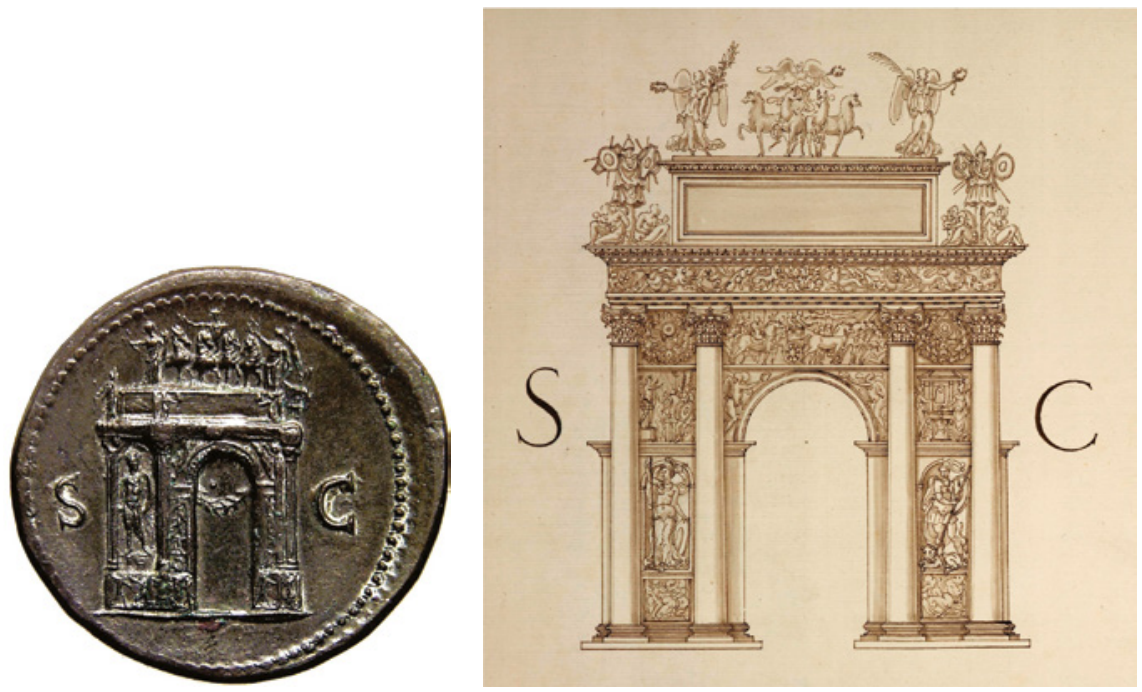

FIGURES 15.24-15.25 Reverse of a coin of Nero, showing a Triumphal Arch, compared to Strada's design of a similar type, in his Magnum ac novum opus in Gotha, vol. 11, fol. 27.

Arches, such as those of Titus or Septimius Severus. Moreover, Strada delved among the graphic examples of his Musaeum for inspiration in rendering his details. Thus the two reliefs of an adlocutio and a sacrifice on either side of the arch are free adaptations of similar scenes preserved in Rome, such as the reliefs of the lost Arch of Marcus Aurelius now in the Palazzo dei Conservatori, or the Hadrianic reliefs on the Arch of Constantine. 

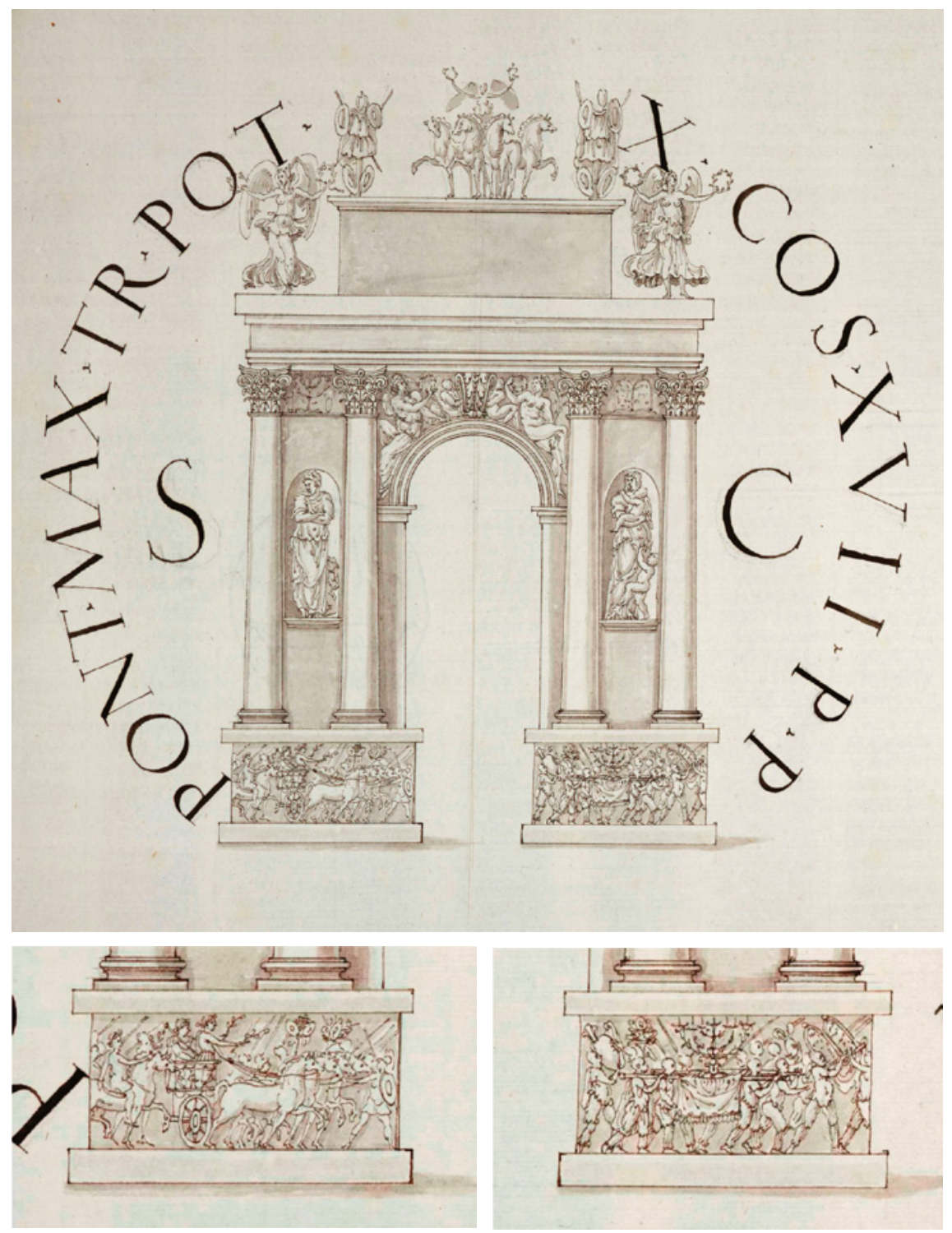

FIGURES 15.26-15.28 Jacopo Strada, drawings of the reverse of a coin of Vespasian, in his Magnum ac novum opus in Gotha, vol. 11, fol. 17, showing a triumphal arch; and details of its socle zone including free versions of the reliefs on the inside of the the Arch of Titus in the Forum Romanum.

In a similar reconstruction of a triumphal arch [Figs. 15.26-15.28] Strada adapted the decorative scenes of the socle zone directly from the two famous reliefs of the triumph after the Judaean War on the inside of the Arch of Titus. The trophies, the quadriga and the Victories on top of the arch are very similar to 
his own drawings of coin reverses elsewhere in the albums; the figures in the niches, however, seem to derive from contemporary example, such as the stucco reliefs designed by Polidoro da Caravaggio.

As discussed in Chapter 2, Strada first learned to document antiquarian material in the immediate circle of Giulio Romano, on the basis not only of Giulio's own splendid numismatic collection, which is cited as the source of

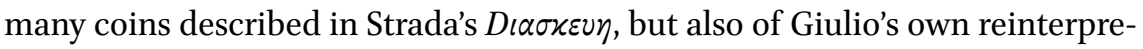
tation of such sources. A good example is Strada's reconstruction of the Pons Aelius in Rome, now known as Ponte Sant'Angelo [Fig. 15.31]. Though ostensibly based on a Hadrianic coin type, which in fact appears to have been a Renaissance invention [Fig. 15.29], Strada's drawing [Fig. 15.30] owed a lot to Giulio's reconstruction of that monument in the background of his Vision of
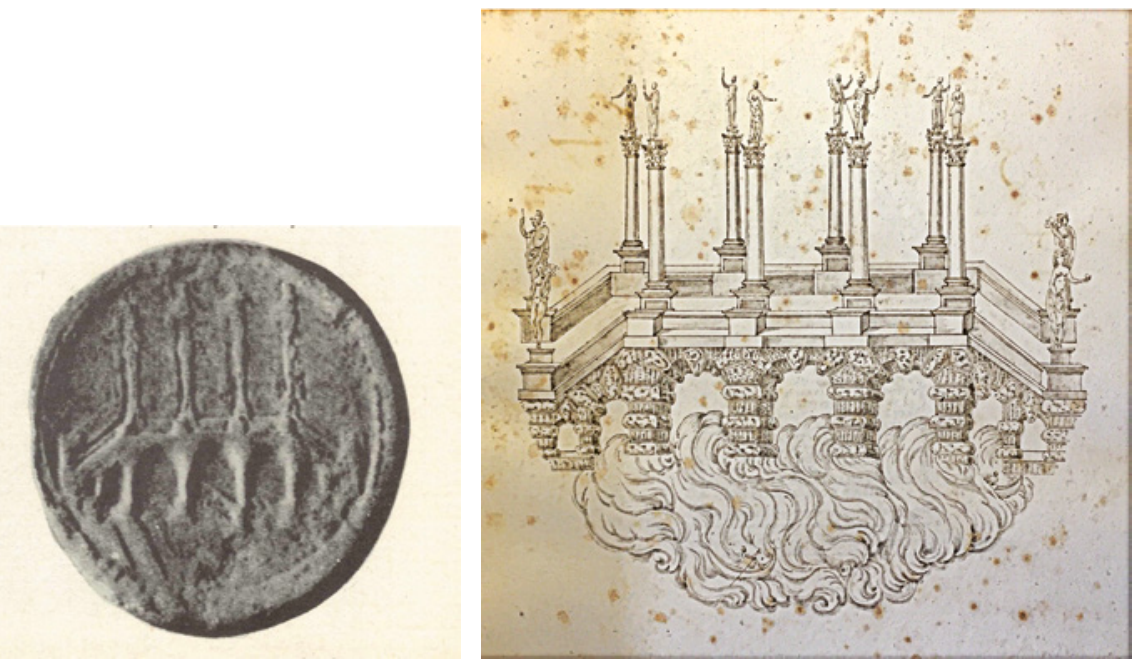

FIGURES 15.29-15.30 A spurious coin of Hadrian, probably a sixteenth- century imitation, showing the Pons Aelius, compared to Strada's drawing of the type in his Vienna Series, önb-hs, ms. 9414, f. 33.

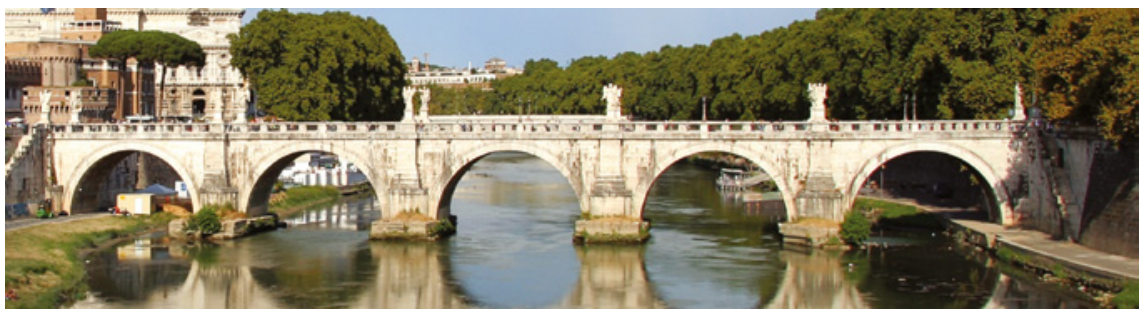

FIGURE 15.31

The Pons Aelius, now Ponte Sant'Angelo, in Rome (second century ad, balustrade and sculptures seventeenth century). 

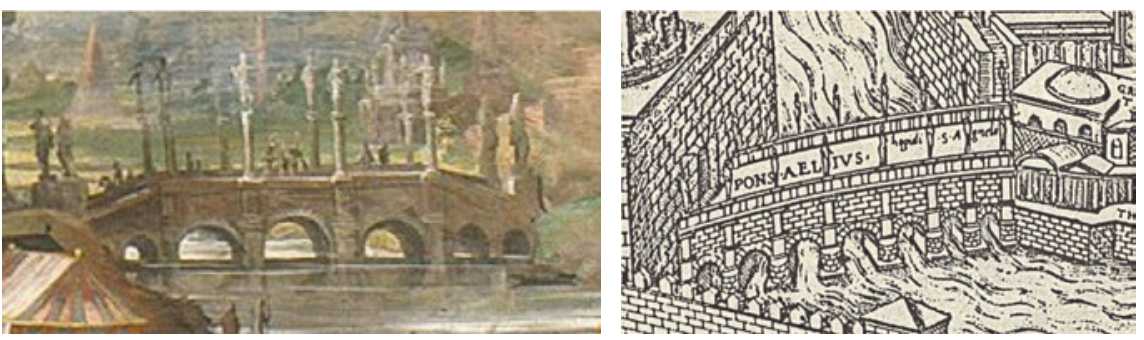

FIGURES 15.32-15.33 Giulio Romano, the Pons Aelius, detail of his fresco The Vision of the Cross, Sala di Costantino, Vatican Palace, compared with Pirro Ligorio's reconstruction in his Anteiquae Urbis Imago.
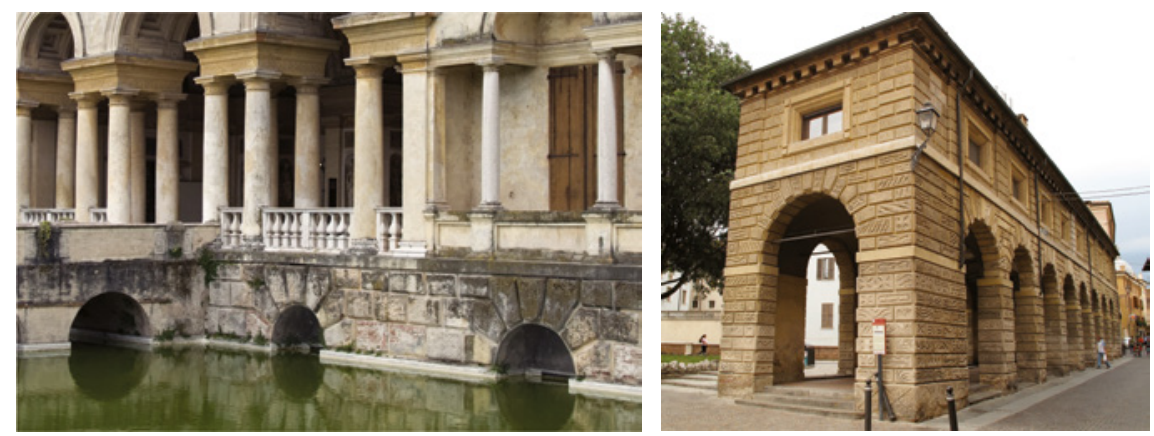

FIGUReS 15.34-15.35 Giulio Romano, garden facade of the Palazzo del Te and the Pescheria or covered fish market, both in Mantua.

the Cross in the Sala di Costantino in the Vatican Palace [Fig. 15.32], which was based on the same coin-type and on the bridge as existent at the time. ${ }^{28}$

That Strada followed Giulio's interpretation is borne out by a comparison with the rather different reconstruction in Pirro Ligorio Anteiquae Urbis Imago of 1561 [Fig. 15.33]. But Strada was faithful neither to the coin, nor to Giulio's model, nor even to the still existing bridge: he reconstructed its substructure as though executed in bugnato, heavy rustica masonry.

In this he appears here to have inspired himself on contemporary architecture, such as Giulio's garden facade of the Palazzo del Te or his Pescheria in Mantua, rather than directly on classical models [Figs. 15.34-15.35]. This means that he presented the bridge not as it is actually shown in the reverse, but as he thought it originally looked like, or perhaps even as he thought it ought to have been depicted on the coin. A parallel to this high esteem for contemporary

28 In view of the close correspondence between the Renaissance imitation and the fresco, it cannot be excluded that the imitation may have been based on Giulio's reconstruction, rather than the other way around. 
reinterpretations of the ancient model is found in the Index sive catalogus, in which his set of drawings of Giulio Romano's frieze in the Camera degli Stucchi in the Palazzo del Te was proposed for publication in the same terms as those of the spiral friezes of the Columns of Trajan and Marcus Aurelius, and was presented as similar and equivalent as a source of information on the military prowess of the Roman Empire. ${ }^{29}$

\subsection{Strada's Aims}

Altogether, it appears that Strada attempted to unite three different, not always easily compatible aims:

- he wished to collect, document and study the remains of the past, and thus to contribute to a better understanding and appreciation of its glories, in particular of the Roman Empire;

- he wished to disseminate the material he collected to a wider interested public, at first through the drawings he made for Hans Jakob Fugger's library, but soon also in print, as has been related in Chapter 14 .

This ambition was not limited to purely historical and antiquarian subjects, but soon became encyclopaedic in character, as is clear from Strada's editorial projects discussed in that chapter:

- in addition to the advancement of learning about the glorious past, it was also Strada's ambition to exploit - and to help his patrons and readers exploit - its greatest achievements: he wished to further the use of Antiquity and of the works of its Italian emulators as examples for contemporary projects.

\subsubsection{The Glories of Antiquity}

There can be no doubt that Strada was deeply interested in the actual, authentic material relics of the past; he went literally out of his way to find rare authentic pieces, as the list of collections he visited makes clear. His practice of including empty circles in his Epitome, in lieu of the coins of those rulers of whom he had not (yet) found a reliable numismatic image, indicates his ambition to provide authentic sources. As such he must be taken more seriously as a scholarly antiquary than at least some of his colleagues: he certainly did not invent quantities of images wholesale, as did Guillaume Rouillé in his Promptuarium. 
Nevertheless, from Strada's selection and in his representation of the objects included, it appears that his concept of authenticity was rather different from ours, and even from that of some of his contemporaries. Though he was quite aware of the existence of very deceptive forgeries, and explicitly warns for these, in practice he was rather uncritical. Thus he included many images and descriptions of coins which appear not to have existed in exactly that form, as was noted even by some of his contemporaries. He may occasionally have been taken in by excellent imitations such as Cavino's, or outright fakes, but it is more likely that he sometimes inadvertently or deliberately mixed up his drawings and his notes. Thus he ranged among the gold coins a head or a reverse which probably exists only in bronze; he borrowed an inscription from one coin-type to restore a damaged original of another type; or he combined obverse and reverse of different coins to come up with a convincing ensemble.

It seems that for him true authenticity was to be found in showing the objects as they were in their prime: thus he also restored in pen-and-ink many of the statues included in his manuscript Statuarum antiquarum, and was involved in the restorations of the actual marbles he acquired on behalf of the Duke of Bavaria. Moreover, like a humanist philologist intent not only in restoring an ancient text, but also in emending it to make it more comprehensible, Strada thought it quite legitimate to show a coin as it should have been designed, rather than as it was, in order better to convey the 'grandeur that was Rome'. As a method this is questionable: Strada forgot that the humanist editor always emended later, defective copies, and in his emendation tried to reconstitute the lost original; whereas Strada's 'emendation' improves on the original itself, at the expense of what we would consider the authenticity of his documentation.
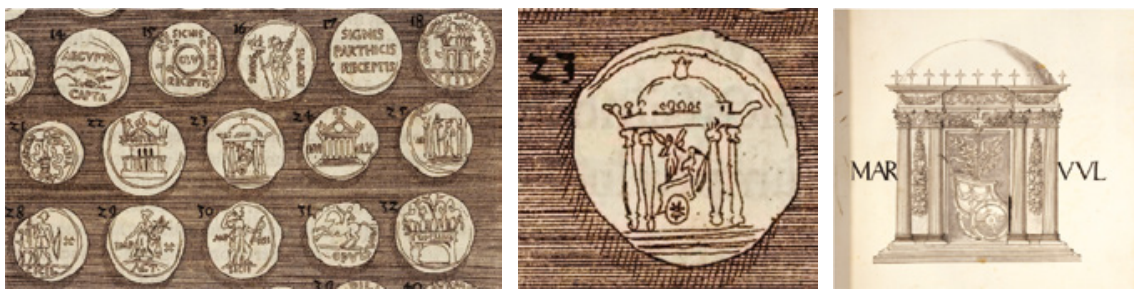

FIGURES 15.36-15.38 Details from the 'Specimen exile' of Wolfgang Lazius' planned catalogue of the Imperial coin collection, compared to Strada's drawing of a reverse of a coin of Vespasian showing a similar round or tetrastyle temple, in his Magnum ac novum opus in Gotha, vol. 5 , fol. 41. 
Strada's drawings present idealized images of their objects, not merely restoring the damage caused by time and use, but also improving the original design. It provides the observer with an ideal representation or reconstruction of Antiquity. If that was Strada's aim, it is easy to understand his criticism of the way in which Wolfgang Lazius and his engraver, Hans Lautensack, had reproduced the coins in the sample they had had printed to promote their planned illustrated catalogue of the Imperial collection [Figs. 15.36-15.37]:

Even if a medal is somewhat defective, it does not for that reason loose the perfection of its design. They [Lazius and his engraver] look at nothing but the outside contours, showing the damage to the rim; so that whoever looks at it will conclude that His Majesty has the most unsightly ['goffe'] medals in the world. ${ }^{30}$

There is a world of difference indeed between Lazius' and Lautensack's careful rendering of the actual coins in Ferdinand's collection and Strada's own detailed drawing of a restored reverse, drawn at roughly five times the size of the numismatic model, which allows a careful reconstruction of the monument it illustrates [Fig. 15.38]. In Strada's eyes Ferdinand was not served by Lautensack's 'clumsy' engravings of second-rate and damaged objects, however authentic, but only by beautiful and refined images evoking the splendour of the Emperor's august predecessors, which helped enhance his prestige. When Strada distinguishes his 'profession' or vocation from that of Lazius, he implied two distinct, but equivalent, competences. He prized his capacity to provide such careful reconstructions, visual interpretations or explanations of the objects and their iconography, as highly as his purely antiquarian expertise, which allowed him to accurately transcribe and interpret the inscriptions on the coins, to attribute them correctly, and to place them in the context provided by the relevant literary sources.

In June 1559, Strada referred in a letter to Fugger to the 'interpretatione' his fellow antiquary Antoine Morillon had provided of the ancient stelae, altars and tombs illustrated in an album in the possession of Cardinal Granvelle. He praised Morillon not only for his industry ('fatica') but also for his ingenuity (Morillon was 'capriccioso'), which had enabled him to get right ('indovinare',

30 Lazius 1558; Jacopo Strada to Martín de Guzmán, Doc. 1558-02-21(b), transcribed in Appendix A. It should be noted that Strada also criticized the rendering of the inscriptions on the coins, which were often mistaken, causing many coins to be assigned to the wrong ruler; doubtless it was this, rather than the way they were reproduced, that moved Antonio Agustín to support Strada in the ensuing controversy. 
that is: to guess) the significance of most, if not all of the objects depicted. ${ }^{31}$ 'Capriccioso': for Strada such caprice represented the ingenuity, the historical and the visual-perhaps even the poetical-imagination he held to be an important, perhaps indispensable adjunct to the scholarly erudition that an antiquary needed to come up with a satisfying - that is, both convincing and pleasing - reconstitution and interpretation of an ancient monument or artefact.

Strada's reconstructions discussed above give some inkling of what he considered convincing and pleasing. That differs very considerably from the norm maintained by some of his contemporaries, such as Lazius, Panvinio and Agustín. But his approach does not differ so very much from that of Guillaume du Choul, who used some of Strada's reconstructions to illustrate his own treatises reconstructing aspects of classical Antiquity [above, Ch. 3.5.3, Figs. 3.55-3.57]. And it is equally close to Serlio's, who exploited his considerable, well-informed imagination in a similar way when representing the ancient monuments of Rome or reconstructing the Roman Castra as described by Polybius.

There is a case to be made that both Strada's image of Antiquity and his antiquarian approach ultimately hark back to his earliest Mantuan memories, to even before the advent of Giulio Romano. They are ultimately rooted in his admiration for the works realized in Mantua by Andrea Mantegna and his followers at the end of the Quattrocento, which were as reverent of the Classical past as Giulio's. In his article, 'Archaeology and Romance', Charles Mitchell discussed the archaeological excursion cum picnic undertaken by Andrea Mantegna and his friends, the Veronese antiquary Felice Feliciano and the magistrate Samuele da Tradate along the shores of Lake Garda. His conclusion can be applied with equal force to Strada's approach:

$<\ldots>$ their learning $<\ldots$.. $>$ anticipated their objective: they were looking, not so much for novel finds, as for fresh reflections and confirmations of an Antiquity that shone in their imaginations. Antiquity was becoming an ideal of life, rather than an object of inquiry. ${ }^{32}$

\subsubsection{Sharing Knowledge: The Encyclopaedic Ambition}

If Titian's portrait of Strada can be considered an example of that master's psychological penetration, there can be no doubt about the enthusiasm with which Strada shared his possessions and his passions with his patrons,

31 Doc. 1559-06-o6, transcribed in Appendix A.

32 Mitchell 1960, p. 478. 
his colleagues and other interested individuals. Strada's eagerness to divulge and exploit the knowledge he had obtained and the materials he had brought together can be linked to the emphasis on practical use postulated in Samuel Quiccheberg's Inscriptiones vel tituli theatri amplissimi, the first treatise on the constitution of an ideal scientific collection or museum. Both reflect the ideas current in Hans Jakob Fugger's circle, to which Strada and Quiccheberg belonged. Both were influenced by the Bibliotheca Universalis, the first comprehensive general bibliography first published between 1545 and 1549 by Fugger's close associate Conrad Gesner. Through his close connections with the book trade Strada probably was also aware of similar enterprises elsewhere, such as Theodor Zwinger's Theatrum humanae vitae, even before it was first printed in 1565 . He must certainly have been influenced by it after publication, even if only negatively, deciding that his own Dictionarium XI linguarum should be ordered alphabetically, instead of systematically.

But Strada's ambition owed as much to Italian as to German example. The emphasis on the use of classical sources in Strada's dictionary project corresponds with contemporary humanist preoccupations; in particular it reflects ideas current in the learned circles around the Papal Curia in Rome, with which Fugger himself was in close contact. An emphasis on the material remains - as most reliable sources for ancient history - and therefore on antiquarian examination and documentation of inscriptions, coins, objects and figurative works of art was a component of such studies at least since Raphael's appointment, in 1515, as supervisor of all archaeological finds in Rome. Already in his teens in Mantua, Strada had been initiated in these ideas by Raphael's favourite pupil, Giulio Romano, and he had obtained ample first-hand experience in the field during his prolonged sojourns in Rome in the 1530 s and the mid 1550 os. The idea to codify the results of such studies in an alphabetically ordered and illustrated dictionary or encyclopaedia was initiated in this Roman circle, and various relics of these efforts are preserved, for instance in the work of Strada's colleague, the architect and antiquary Pirro Ligorio. ${ }^{33}$ But Strada's ambition to extend such a work beyond Antiquity and the classical languages appears to have been his own idea. In part it was a logical consequence of his close connection with Fugger, whose interests included the later history of the Holy Roman Empire as well as practical contemporary politics, and in part of Strada's permanence at the multilingual Vienna court, where both ideological and practical reasons created a demand for it. Strada's wish to reach an audience beyond that of the professional intellectuals thus was the consequence of the demand of his patrons, as much as of his own didactic ambitions. 


\subsubsection{Examples to Emulate: Antiquity in Contemporary Dress}

Strada owed his admiration for the ancients and for the works of art they created directly to his apprenticeship in the studio of Giulio Romano, and indirectly to Giulio's teacher Raphael. Their example showed him not only how to document and interpret the material remains of a venerated Antiquity, but also how to translate that experience towards new, original works of art. Considering the splendour, the elegance, the profound understanding of the classical precept that characterizes the work of these two masters, especially in architecture and decoration, it is not surprising that their practice would become a paradigm of excellence for a young, ambitious artist such as Jacopo Strada. The designs of the buildings with which he himself can be associated, such as the Stallburg, his own house and the Neugebäude in Vienna, and his design for the Munich Antiquarium show that he had taken their example to heart. But Strada did not limit his efforts to propagating their legacy and to tacitly following their example in his own works. As discussed in Chapter 13.8, he also commissioned splendid sets of documentary drawings of their principal works, which he intended to publish.

It is important to realize that this project is closely connected to Strada's efforts to publish authentic antique remains. The manner in which he describes Giulio's frieze in the Camera degli Stucchi in the Palazzo del Te, presenting it as the equivalent of the frieze of the Trajanic column, shows that for Strada the emulation of the classical example was not only a possibility but a self-evident artistic necessity. That conviction is reflected not only in his reconstructions of ancient monuments in his numismatic drawings shown above, but also in the mannerist designs for festival costumes and sumptuous gold and silver tableware collected in his libri de' disegni, which were explicitly presented as 'in the antique manner'. The title of the Vienna album of helmets and related headdresses stresses its—not exclusively—antique origins:

Ancient crested helmets such as in the past were used by the Greeks and the Romans and by other peoples both in spectacles and public games, and in the wars; the forms and images whereof have been derived from bronze and marble statues, as well as from bronze, silver and gold coins, and most precisely and exquisitely drawn. ${ }^{34}$

34 Vienna, ÖNB-HS, Cod. min. 21,1: Galearum antiquarum cristatarum quibus olim Graeci et Romani atque alii etiam populi tam in spectaculis et in ludis publicis, quam in bellis usi sunt, formae atque imagines ex aeneis atque marmoreis statuis tum etiam ex aeneis, argenteis aureis que numismatibus desumptae, et elegantissimae aptissimaeque delineatae. Ex Musaeo Jacobi de Stradae. Mantvani. Caess. Antiquarii civis Romani. The same holds for the title of the Dresden album of festival designs (above, Ch. 4.3.5.). 

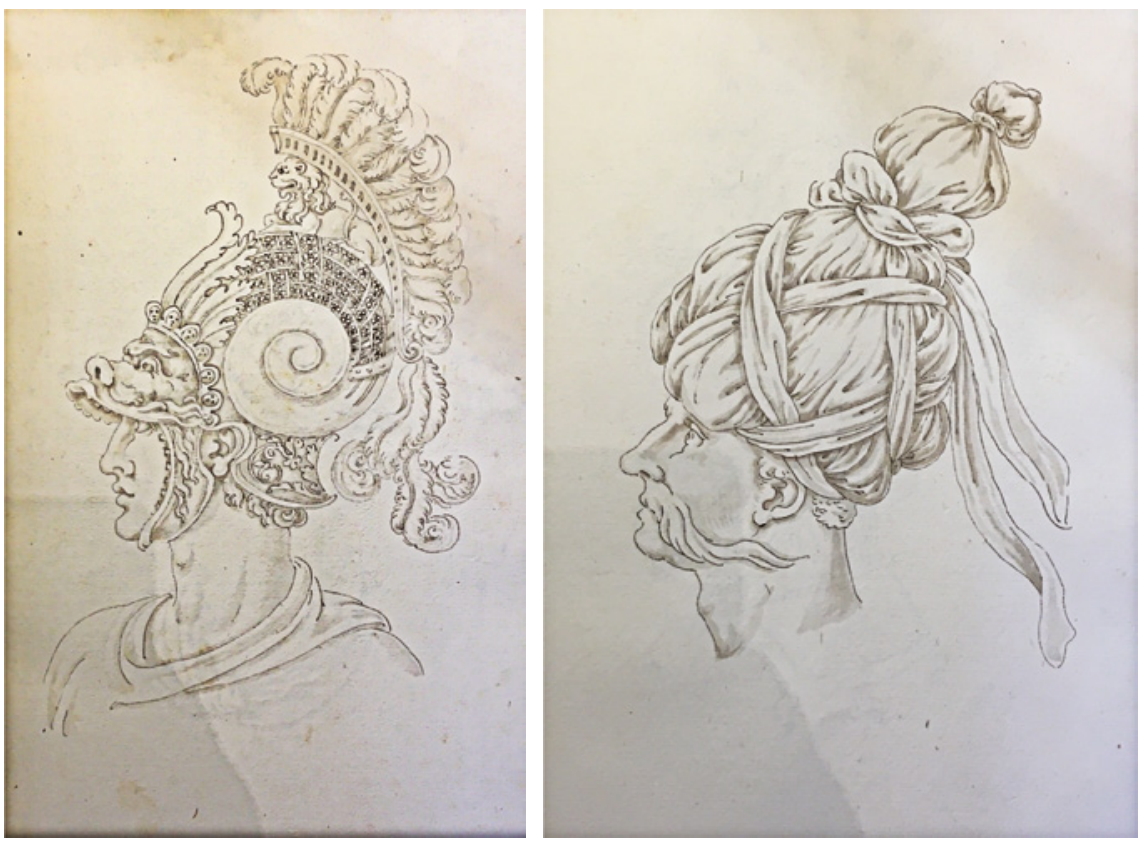

FIGURES 15.39-15.40 Workshop of Jacopo Strada, design for a helmet in the 'antique' style and for a turban ; Vienna, Österreichische Nationalbibliothek, Cod. min. 21,1, fols. 14 and 61 .

Whereas in fact they are largely derived from designs for fanciful costumes made for contemporary festivities-a supposition borne out not only by the style of the designs, but also by the inclusion of Turkish turbans and medieval helmets, reminding one of the many tournaments based on the tales of Ariosto and Tasso and on Amadis de Gaule, for which the originals that Strada copied had been designed [Fig. 15.39-15.40 and above, Figs. 4.26-4.31].

The same holds for the various sets of drawings after ornamental vases that can be attributed to Strada and his workshop, some of which explicitly pose as antiques. Several of these carry inscriptions-not necessarily in Strada's own hand-identifying the alleged finding spots of these vases, or rather more often of 'a similar vase' or 'such a vase'. Instances are 'A vase such as this was found outside of Naples in a vinyeard, it was of silver, and was brought to Rome to Cardinal della Valla" [Fig. 15.41] and "Such a vase as this was found in the Forum of Trajan, and was of gold; a work never seen again in our time, and it was destroyed during the Sack of Rome' [Fig. 15.42]. ${ }^{35}$ Notwithstanding such

35 Two drawings from a set of 61 drawings from an album of at least 66 that was at a later date incorporated in an album in the collections of the Princes Waldburg-Wolfegg. They 

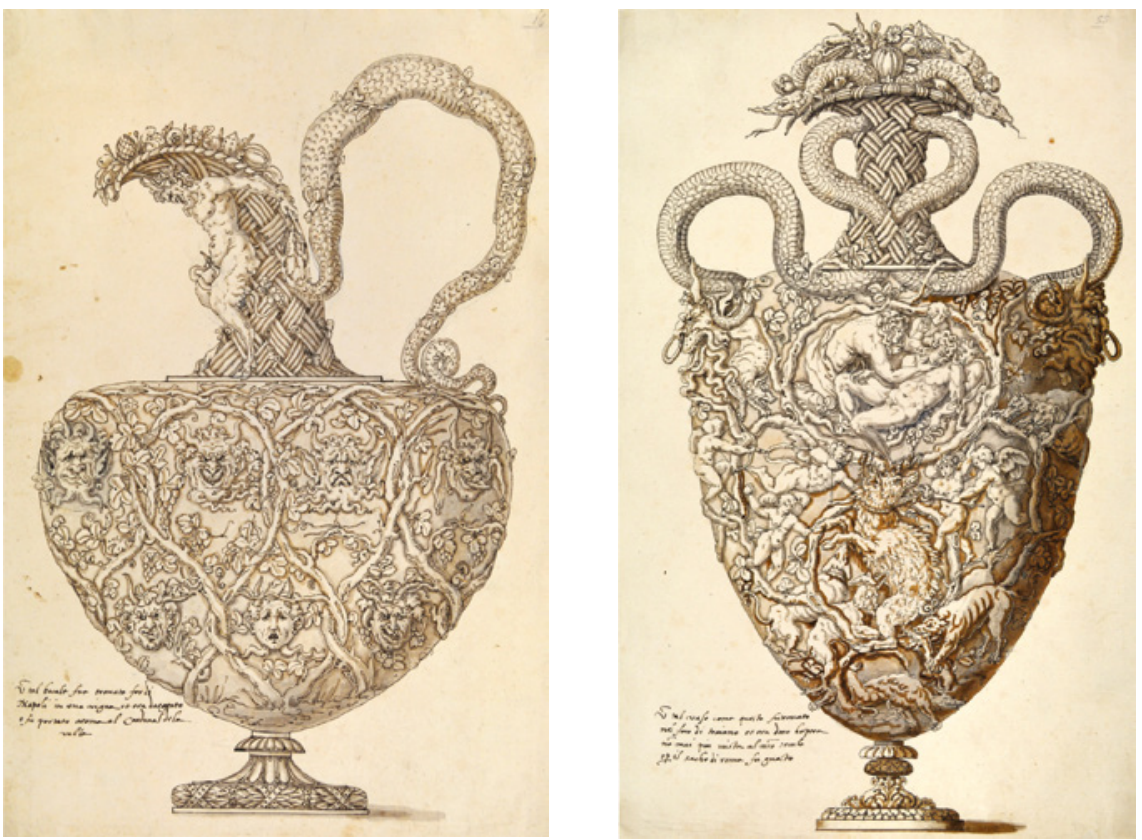

FIGURES 15.41-15.42 Workshop of Jacopo Strada, two designs of an ornamental ewer and a vase; Wolfegg, Kunstsammlungen der Fürsten Waldburg-Wolfegg.

credentials these objects, though in an 'all'antica' style, were all clearly derived from mannerist designs of Giulio Romano and other contemporary mastersthe originals or copies of which could be found in Strada's Musaeum.

Combining antique precept and models with contemporary examples, and combining both in new creations, was by no means rare in the sixteenth century. Strada shared this practice with many of his fellow artists—one thinks of Pirro Ligorio's Casino built for Pope Pius IV in the Vatican gardens. It also appealed to the patrons commissioning building such as the Casino, though it appealed perhaps less to Strada's scholarly acquaintances such as Agustín, who more clearly distinguished between a sixteenth-century Christian present and a glorious, but distant, pagan past that was irrevocably lost.

can be related to several other albums of similar designs from the Stradas' workshop; cf. Hayward 1970; Bukovinská/Fuč́ková/Konečný 1984; Fuhring 2003; Taylor 2014. 